\title{
Comparison of Ukrainian and Turkish Law Students' Attitudes towards Democratic Values: Cross-cultural Study
}

\author{
Fethi Kayalar \\ Faculty of Education, Erzincan University, Turkey
}

Copyright (C) 2016 by authors, all rights reserved. Authors agree that this article remains permanently open access under the terms of the Creative Commons Attribution License 4.0 International License

\begin{abstract}
The aim of this study is to examine Ukrainian and Turkish law students' attitudes towards democratic values and the factors that may affect these values and to compare them in terms of different variables. This study is a descriptive survey model. The research consists of total 226 students from three Schools of Law, two in Turkey and one in Ukraine, whose race, religion, culture and languages are different. We tried to determine their attitudes towards democratic values regarding as age, gender, grade, level of parents' education, accommodation types. We applied "Democratic Values Scale" with 17 items developed by Çermik. We have concluded that comprehensive democratic activities should be created and the curriculum equipped with democratic values should be regulated and implemented so that potential future lawyers, legists, policy makers, politicians and administrators to be graduated from Schools of Law can eliminate discrimination and distribute the rights equally and establish democratic order and social justice, promote and defend the freedom of thought.
\end{abstract}

Keywords Democratic Values, Law Education, Democratic Values Scale, Ukrainian Democracy, Turkish Democracy

\section{Introduction}

The aim of this study is to examine the vision, mission and values of Law Schools and democratic values of Law students in Turkey and Ukraine in the frame of cross cultural comparison, and the factors that may affect these values in terms of different variables.

\subsection{Democracy and Democratic Values}

Democracy is a set of ideas and principles about freedom, but it also consists of a set of practices and procedures that have been moulded through a long, often winding history. In his article, Gayechuway[1] argues that the right to equality before the law, or equal protection of the law as it is often emphasized, is fundamental to any just and democratic society. Whether rich or poor, ethnic majority or religious minority, political ally of the state or opponent, all are entitled to equal protection before the law. As shown in Table 1, democratic values are categorised into fundamental beliefs which include life, liberty, the pursuit of happiness, common good, justice, equality, diversity, truth, popular sovereignty, patriotism, and constitutional principles which include rule of law, separation of powers, representative government, checks and balances, individual rights, freedom of religion, federalism, civilian control of the military. One of the basis of democratic thoughts, multiculturalism is not restricted to colour of people, in fact it is a universal issue that needs implementation in educational institutions, on all levels [2].

\begin{tabular}{|l} 
Table 1. Democratic values \\
\begin{tabular}{|c|l|}
\hline Fundamental Beliefs & $\begin{array}{l}\text { Life, Liberty, The Pursuit of Happiness, Common } \\
\text { Good, Justice, Equality, Diversity, Truth, Popular } \\
\text { Sovereignty, Patriotism }\end{array}$ \\
\hline Constitutional \\
Principles & $\begin{array}{l}\text { Rule of Law, Separation of Powers, } \\
\text { Representative Government, Checks and } \\
\text { Balances, Individual Rights, Freedom of Religion, } \\
\text { Federalism, Civilian Control of the Military. }\end{array}$ \\
\hline
\end{tabular}
\end{tabular}

Apart from these values, majority rule, minority rights, fair elections, equality before the law, government based on consent of the governed, guarantee of basic human rights, due process of law, constitutional limits on government, social, economic, and political pluralism, values of tolerance, pragmatism, cooperation, and compromise are the pillars upon which a democratic society rests. Besides policy makers and administrators, the lawyers, legists and advocators have fairly heavy duties to establish these democratic values and ideas in the core of a society. 


\subsection{Schools of Law, Law Students and Graduates}

As regards the democratic values, the visions of Law Schools in various parts of the world are engaging with the community and the University at all levels of work, including teaching, scholarship, public service, and public policy, creating and disseminating knowledge to solve social and legal problems and to promote justice, achieving the goals through an integrated program of instruction that connects skills and knowledge, applies theory to practice, and respects and engages diverse points of view and diverse experiences. Respecting for the rights, differences, and dignity of others, and being honesty and integrity in all dealings are among the core values of Harvard Law School's, one of the most prestigious schools of Law in the world.
The most important values that the Law Schools hold are contributing to a just society, fostering inclusiveness and respect, improving the legal system, building and maintaining strong connections with the legal community, espousing the virtues of truth, integrity, honesty, tolerance, professionalism, teamwork and meritocracy, upholding the ethics and etiquette of teaching, learning and research, promote and defend the freedom of thought and academic enquiry as well as freedom of association, ensuring openness and transparency in all its dealings and operations, nurturing responsible corporate citizenship and strong social responsibility, respecting the beliefs and values of others, respecting and protecting the environment, having the courage to initiate and adapting to change and respecting the beliefs and values of others.

Table 2. Visions, Missions and Values of School of Laws all over the World.

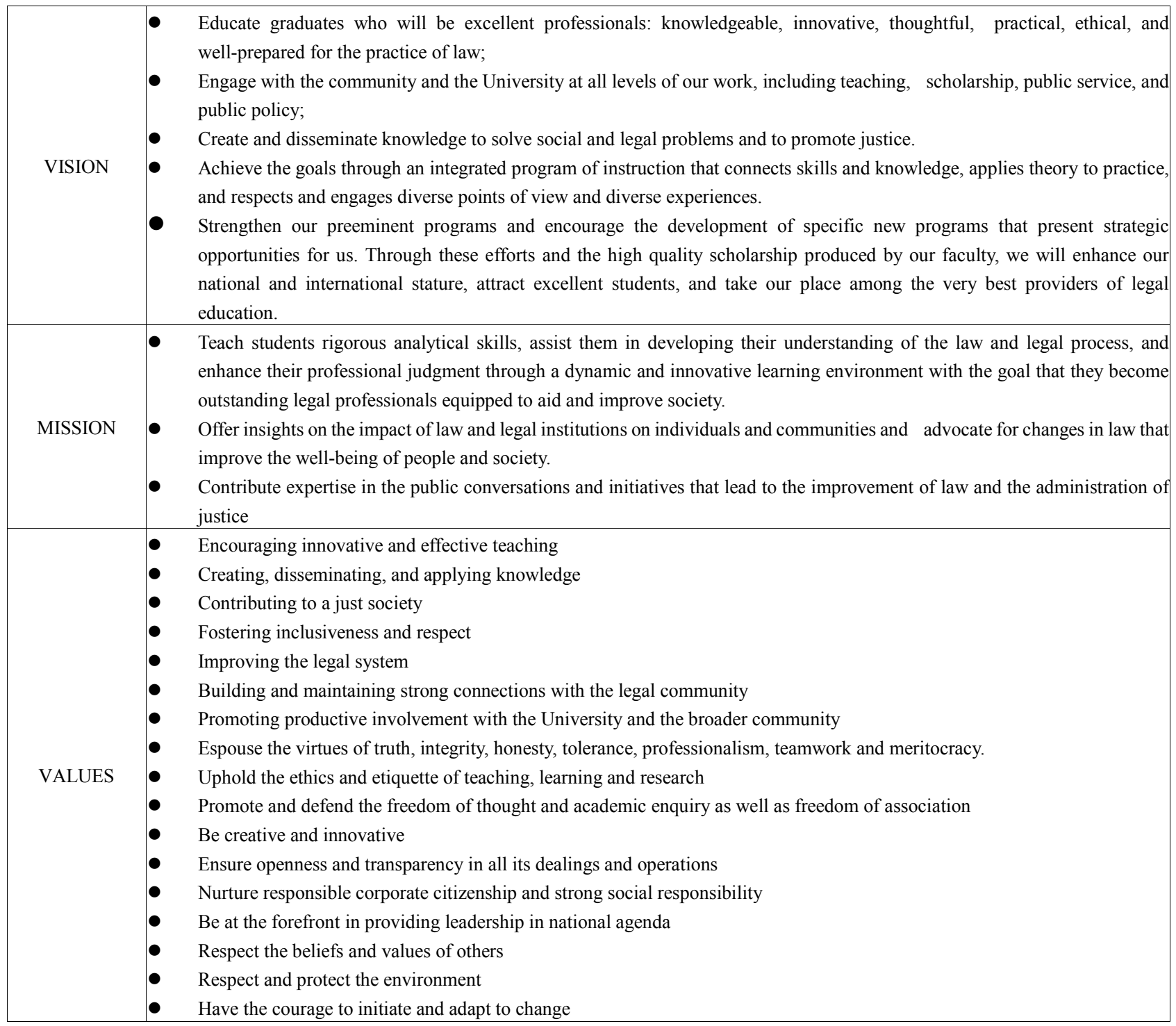

Table content is taken from the website of The Sturm College of Law (2015) 
The policy makers, administrators, lawyers, legists, advocators and solicitors are mostly those having graduated from Schools of Law. That is why we carried out this study on law students in two different countries whose religious, languages, cultures, values and norms are different, and tried to determine their attitudes towards democratic values. As shown in Table 2, the vision, mission and core values of Law Schools put emphasis on how important the democratic values are for Law students and graduates.

\subsection{Democracy in Turkey}

Turkey has been experiencing great changes and dramatic transformations in the way to democracy and judicial system in recent years. From the early 2000s onward, Turkey has managed to implement democratic reforms to make its way for greater stability. Besides, Turkey's attempt and efforts to join the European Union helped drive these changes [3].

At the other, the modern Turkish state with an authoritarian character views different identities, ethnicities and ideologies as a threat to its existence. However, the conditions and circumstances have gradually begun to improve over the past ten years. For instance, with the Parliament passing two constitutional amendments to repeal the headscarf ban in 2008 and military coups, further changes and transformations are under way to achieve full democratization in Turkey.

\subsection{Democracy in Ukraine}

Ukraine achieved independence in 1991, but hardly has democratic revolution existed since then. The fact that Ukraine has signed treaty of close relationship with European Unity gives her a big chance and opportunity to institute permanent democracy that her people have longed for since the collapse of Soviet Communism. The collapse of the Communist bloc in 1989, then the Soviet Union in 1991 left a void in the educational policies of the former Soviet republics [4]. As a result, Russian lost the predominance it previously had in several cases. One of the most significant challenging was the dichotomy of formal-informal and state-people's language use. With the introduction of Ukrainian as the sole state language and language of instruction as a part of democratic progress, a great number of citizens preferring to use Russian generated some paradoxes. Likewise, several Soviet republics passed a law on national language in the same year. In Ukraine, the law adopted a number of regulations to limit the use of Russian, which made Ukrainian the main language [5]. Ukrainian citizens were allowed to be educated in other languages when a consistent minority was present, which enabled bilingual education to emerge as an incidence of democratic right. The ideological position behind this is that a country must have an official language and that this can also help the consolidation of a national identity and its democratic stability and decisiveness.

Both countries have many similarities in that they have different ethnics, minorities, cultures and political views. Therefore, democratic values are very important for Law students to distribute the rights equally to every class of people in their professions of law, justice, management and administration.

\section{Literature Review}

According to Charles and Trevor[6], Ukraine has weathered some key challenges to its young democracy. While significant challenges remain, the early successes provide an initial basis for some confidence that the consolidation process will continue to the next stage. The roots of democracy in Ukraine are not yet deep, but they have begun to spread.

Boyko et al.[7] stated that it is required to provide civic education, ensure a secure chain of custody for ballots, distribute ballots to voters, count votes, certify results, and adjudicate disputes, which should be conducted with adequate assurances as a part of democratic values to meet democratic standards in Ukraine.

Medvedev[8] found that $38 \%$ of the population reported using only Ukrainian, $30 \%$ only Russian, and $31 \%$ reported using both, depending on the situation. These statistics portray a balance between Russian and Ukrainian, but a closer look reveals ethnolinguistic inequality. Bilingualism is one of the inevitable conditions of democratic values and democratic right for speaking mother tongue.

Tereshchenko[9], in his study, has argued that young people, constructed as passive and cynical by teachers, as well as in much academic and political discourse, are critical and, in fact, not disengaged. They showed an ability to make sophisticated judgements about various aspects of social and political life, critically appraise their education and suggest a number of practical democratic improvements to it.

Frye[10] states in his research that economic ties of Ukraine with Russia are a proxy for political views. People opposing closer economic ties with Russia put a higher value on democracy than the others who are in favor of Russian policies and oppose Russia's more autocratic government. Those holding more democratic values are less likely to support close economic ties with Russia.

According to Gayechuway [1], the right to equality before the law, or equal protection of the law as it is often phrased, is fundamental to any just and democratic society. Whether rich or poor, ethnic majority or religious minority, political ally of the state or opponent, all are entitled to equal protection before the law.

In Ukraine, the US followed the pattern of the European Unity in terms of assuming the commitment to democracy and the rule of law after the Orange Revolution. Democracy promotion is only effective when there is a receptive domestic constituency.

Through globalization, the increasing international procedures among countries give rise to legal practitioners' duties, which means that lawyers need to develop the 
necessary knowledge and skills in the areas of law, international law, and the law of other nations [11], the norms and values of other nations as well as the democratic values and views in universal frame.

The analysis by Ivan Katchanovski[12] shows limited effects of historical democratic legacies and Catholicism on pro-democracy views. With some exceptions, adherents of major parties do not differ significantly in terms of their degree of support for democracy. This study suggests that partially democratic and partially authoritarian political culture impedes the future prospects for consolidated democracy in Ukraine.

\section{Materials and Method}

\subsection{Problems of the Research}

This study is a descriptive survey model. The problems of the research are (1) What are the democratic values of the students in the fields of Law and Justice in different countries and the factors affecting democratic values? (2) Are democratic values of Law students significantly different in terms of their countries, genders, age, educational programs, their parents' education levels and accommodation places?

\subsection{Participants}

The research consists of total 226 students from three Schools of Law, two in Turkey and one in Ukraine, whose race, religion, culture and languages are different and we tried to determine their democratic values regarding as age, gender, grade, parents' educational level, accommodation types. The participants, regardless of their gender, grades and ages, were chosen randomly in three schools of law in Turkey and Ukraine through the permission of the deans of the schools. The participants were asked of their consent for the survey. The number of the participants from Turkey is 168 , and that from Ukraine is 58 . Of all the participants in our study, 141 are females and 85 males.

\subsection{Research Instrument}

We applied "Democratic Values Scale" (DVS) with 17 items developed by Çermik[13]. DVS is a five-degree Likert type scale consisting of a total of 17 items collected under 4 factors such as 'Seeking fairness', 'Respect to differences', 'Justice' and 'Equity', and these factors were statistically examined as to relationships between each other. The data obtained from a total of 226 participants were analyzed through Social Science Statistics Programme (SPSS 20.0). The data obtained with Democratic Values Scale (DVS) were also analyzed in terms of reliability through Cronbach Alpha. The alpha coefficient for the sixteen items was found .886 , suggesting that the items have relatively high internal

\section{Findings and Discussion}

Out of the all participants in the study, 141 are females $(62,4 \%)$, and 85 were males $(37,6 \%)$ as shown in Table 3 .

Table 3. The number and the percentages of the participants as to gender

\begin{tabular}{cccc}
\hline Variables & & f & \% \\
\hline Gender & Male & 85 & 37,6 \\
\hline & Female & 141 & 62,4 \\
\hline & Total & 226 & 100,0 \\
\hline
\end{tabular}

We evaluated the age ranks of the participants in three groups as one group 18-20 years of age, another group 21-23 years of age and the last group 24 and over years of age as in Table 4 . The average ages of the participants is 22,6 years. Of the participants, 59 are 18-20 years of age (26,1\%), 157 are $21-23$ years of age $(69,5 \%)$ and 10 are over 24 years of age $(4,4 \%)$.

Table 4. The number and the percentages of the participants as to age

\begin{tabular}{cccc}
\hline Variables & & f & $\mathbf{\%}$ \\
\hline Age & 18-20 years of age & 59 & 26,1 \\
& $21-23$ years of age & 157 & 69,5 \\
& $24+$ years of age & 10 & 4,4 \\
Total & 226 & 100,0 \\
\hline
\end{tabular}

The participants of the study are from two kinds of Law School, one is the Faculty of Law, which has an 8-term academic program, and another is High School of Justice, which is a 4-term academic program, as in Table 5. One hundred and forty participants are students in Faculty of Law, that is School of Law $(61,9 \%)$, eighty-six in High School of Justice $(38,1 \%)$

Table 5. The number and the percentages of the participants as to Faculty and High School

\begin{tabular}{cccc}
\hline Variables & f & \% \\
\hline Faculty & Faculty of Law & 140 & 61,9 \\
& High School of Justice & 86 & 38,1 \\
& Total & & \\
\hline
\end{tabular}

We carried out the research in two countries, Turkey and Ukraine. The number of the participants from Turkey is 168 $(74,3 \%)$ and that from Ukraine is $58(25,7 \%)$ as shown in Table 6.

Table 6. The number and the percentages of the participants as to Country

\begin{tabular}{cccc}
\hline Variables & & $\mathbf{f}$ & $\mathbf{\%}$ \\
\hline Country & Turkey & 168 & 74,3 \\
& Ukraine & 58 & 25,7 \\
& Total & 226 & 100,0 \\
\hline
\end{tabular}

To determine the parents' education levels of the participants, we grouped the levels of education in four groups as Primary School, Secondary School, High School and University. We determined that the education levels of 
the participants' fathers mostly fall in University $(39,4 \%)$, while that of mothers mostly in Primary School (50\%) as shown in Table 7.

Table 7. The number and the percentages of the participants as to Parent's Education Level

\begin{tabular}{lccc}
\hline Variables & & f & \% \\
\hline Education of Father & Primary & 75 & 33,2 \\
& Secondary & 26 & 11,5 \\
& High School & 36 & 15,9 \\
& University & 89 & 39,4 \\
& Total & 226 & 100,0 \\
\hline Education of Mother & Primary & 113 & 50,0 \\
& Secondary & 21 & 9,3 \\
& High School & 28 & 16,8 \\
& University & 54 & 23,9 \\
& Total & 226 & 100,0 \\
\hline
\end{tabular}

We tried to determine accommodation places of the participants, and categorized them in 5 groups as State Dorm, Private Dorm, House shared with friends, House shared with parents and Hostel as shown in Table 8. We determined that 75 of the participants preferred to stay at State Dorm $(33,2 \%)$, 62 at House with parents $(27,4 \%), 42$ at Private Dorm $(18,6 \%), 42$ at House with friends $(18,6 \%)$, and only 5 at Hostel $(2,2 \%)$.

Table 8. The number and the percentages of the participants as to Accommodation Place

\begin{tabular}{cccc}
\hline Variables & & f & $\mathbf{\%}$ \\
\hline Accommodation & State Dorm & 75 & 33,2 \\
& Private Dorm & 42 & 18,6 \\
& House with friends & 42 & 18,6 \\
& House with parents & 62 & 27,4 \\
& Hostel & 5 & 2,2 \\
& Total & 226 & 100,0 \\
\hline
\end{tabular}

To determine the places where the participants' families live, we categorized it in four groups as Metropolis, City Centrum, Town and Village. We found out that the families of 96 participants live in City centrum $(42,5 \%), 56$ in Town $(24,8 \%), 49$ in Village (21,7\%), and 25 in Metropolis $(11,1 \%)$ as shown in Table 9 .

Table 9. The number and the percentages of the participants as to Place Family live in

\begin{tabular}{cccc}
\hline Variables & & f & \% \\
\hline Place of Family & Metropolis & 25 & 11,1 \\
& City Centrum & 96 & 42,5 \\
& Town & 56 & 24,8 \\
& Village & 49 & 21,7 \\
& Total & 226 & 100,0 \\
\hline
\end{tabular}

As the School of Law carries its education in four grades, we categorized it in four grades ranging from $1^{\text {st }}$ grade to $4^{\text {th }}$ grade. We determined that 100 students attend to the $4^{\text {th }}$ grade $(44,2 \%), 54$ to the $2^{\text {nd }}$ grade $(23,9 \%), 43$ to the $1^{\text {st }}$ grade $(19 \%)$ and 29 to the $3^{\text {rd }}$ grade $(12,8 \%)$ as shown in Table 10.

Table 10. The number and the percentages of the participants as to Grades

\begin{tabular}{cccc}
\hline Variables & & $\mathbf{f}$ & $\mathbf{\%}$ \\
\hline Grades & $1^{\text {st }}$ grade & 43 & 19,0 \\
& $2^{\text {nd }}$ grade & 54 & 23,9 \\
& $3^{\text {rd }}$ grade & 29 & 12,8 \\
& $4^{\text {th }}$ grade & 100 & 44,2 \\
& Total & 226 & 100,0 \\
\hline
\end{tabular}

From the analysis of the data, we found that there is no significant difference between Turkish and Ukrainian students for the democratic values as to gender, age, faculty, father's education and living place of family. However, we found significant differences in terms of grades, mother's education, and accommodation places.

The factors of "seeking fairness" and "respect for differences" were found to be greater in the students studying in Ukraine than those in Turkey; however in the factors of "justice" and "equity" the democratic values of the students of the Faculties of Law were found to be greater than those of the High School of Law.

In table 11 , we determined that there is a significant difference between 1st grade and 4th grade, 2nd grade and 4th grade, 3rd grade and 4th grade in favor of 4th grade in terms of democratic values. The understandings and attitudes of the students towards Democratic values can be said to increase gradually from the first year to the last year of the faculty. As they get educated in the Faculty of Law, the democratic values become the parts of their lives and minds. It can be said that the Faculty of Law achieves and fulfils its mission and vision to bring in democratic values to its students gradually from the first year to the last year.

Table 11. Analysis of the Democratic Values of the participants in terms of Grades

\begin{tabular}{cccccc}
\hline Grades & $\begin{array}{c}\text { Total } \\
\text { Squares }\end{array}$ & sd & $\begin{array}{c}\text { Mean } \\
\text { Squares }\end{array}$ & F & p \\
\hline Between Groups & 1257,160 & 3 & 419,053 & 5,009 & $0,002 *$ \\
Within Groups & 18572,774 & 222 & 83,661 & & \\
Total & 19829,934 & 225 & & & \\
\hline
\end{tabular}

In table 12 , there is a significant difference between elementary education and university education as well as high school education and university education in terms of mother's education levels for democratic values. As the education levels increase, so do the democratic values. From the data on education levels of the participants' mothers, we can argue that the mothers have a great impact on their children to adopt democratic values.

Democracy Education first begins in family. While some decisions are made, members of the family participate in the task and the common decisions are employed in the family. In democratic families, the children are allowed to participate in decision so they can tell their ideas freely, 
hence respectful to others views and rights. From this point of view, the education of family, particularly mother's education, is of great importance for the children to learn democratic values. In the study, the participants whose mothers are university graduate were determined to have more understanding of democratic values than the others.

Table 12. Analysis of the Democratic Values of the participants in terms of Mother Education

\begin{tabular}{cccccc}
\hline $\begin{array}{c}\text { Mother } \\
\text { Education }\end{array}$ & Total Squares & sd & $\begin{array}{c}\text { Mean } \\
\text { Squares }\end{array}$ & F & p \\
\hline Between Groups & 1512,558 & 3 & 504,186 & 6,111 & 0,001 \\
Within Groups & 18317,376 & 222 & 82,511 & & \\
Total & 19829,934 & 225 & & & \\
\hline
\end{tabular}

From the analysis of the data in terms of accommodation places of the participant, we found that there is a significant difference between state dormitory and private dormitory, state dormitory and house with family, state dormitory and house with parents in terms of accommodation places of the students for democratic values. The more crowded the place the students stay at, the more democratic values they have. It appears that the common sharing by the students in student dorms increase the awareness of democratic values, as they have to share the room, bath, toilet, canteen, table, desks, etc. The school and dormitory environment are very important for university students to cooperate, collaborate and share with each other thus acquiring democratic values. As shown in table 13, with Kruskal Wallis test, the level of the democratic values of the participants staying at State dorms is significantly higher than those living in houses with family or friends. The more crowded environment the students live in, the more democratic values they have.

Table 13. Analysis of the Democratic Values of the participants in terms of Mother Education Kruskal Wallis

\begin{tabular}{cccccc}
\hline Accommodation & N & Mean & sd & $\mathbf{X}^{\mathbf{2}}$ & $\mathbf{p}$ \\
\hline 1 State Dorm & 75 & 141,19 & 4 & 25,062 & 0,000 \\
2 Private Dorm & 42 & 113,86 & & & \\
3 House with friends & 42 & 92,06 & & & \\
4 House with family & 62 & 98,99 & & & \\
5 Host & 5 & 55,20 & & & \\
\hline
\end{tabular}

\section{Conclusions and Suggestions}

According to the variable of accommodation place, the democratic values of the students staying at crowded places like dorms and hostels are determined to be significantly higher than those at places like home where very few people live. Respectful that the people living in the countries like Turkey and Ukraine have different cultures, different languages, and different ethnics, we have concluded that comprehensive activities should be created and the curriculum should be regulated and prepared so as to eliminate discrimination and distribute the rights equally especially in regard of Law students paying more attention to democratic values.

As Ferguson suggests in the study, we should make efforts to integrate the seeds, thoughts, and actions of ethics, well-being, and professionalism into aspects of each of school programs as possible [14].

Based on the work by Gentile [15], Giving Voice to Values (GVV) aims to help students learn to not merely recognize ethical conflicts, but rather know that they have the skills to act on their values when the conflicts arise, such as understanding the scope and limits of general values, knowing that values conflicts will occur, becoming aware of the many common reasons and rationalizations they will receive from others to justify unethical behavior, knowing their own purposes and values, and providing them with the opportunity to practice the skills in order to provide them with the choice to voice their values in conflict situations.

Family, school and other educational institutions have a different impact on individuals in different periods according to the development periods of the individual. According to Erden and Akman [16], the first years after birth is a critical period as to growth of personality and the behaviors and attitudes acquired in childhood period are permanent. The researches carried out on children have shown that the basic features of personality significantly develop within the first five years after birth [17]; [18]; [19]. The influence of childhood period continues lifelong [20]. Acquired basic orientation in this period significantly affects the future life. By providing the necessary training to individuals at an early age, a psychological basis is created to shape the values. On the other hand, students' racial attitudes can be modified and made more democratic and that the racial attitudes of young children are much more easily modified than the attitudes of older students and adults [21]. Thus, early exposure to a multicultural curriculum has the most likelihood of success [22].

Rather than father, mother has significant influence on child's psychological, educational and academic development. In the study the democratic values of the participants were determined higher in those whose mothers' educational levels are higher than the others. The educational levels of the mothers can be said to have important effect on making the children acquire democratic values. For this reason, parent's education, particularly mother education, should be put emphasis in child education within the early years.

Anderson et al.[23] determined in his research that one in five students report that their law school gives very little emphasis to encouraging contact with students from different economic, social, or racial or ethnic backgrounds. Eighteen percent of students feel that their law school contributes very little to developing a personal code of values and ethics. However, in our study, the data obtained from the students of School of Law in Turkey and Ukraine show that the Law schools contribute much too developing democratic values and ethics particularly toward the last years of their law education. Thus, various programs over democratic values should be added to curriculum in the first years of education 
in Schools of Law. Anderson [24] argues that complementary learning activities inside and outside the classroom augment, enrich and deepen student learning. A supportive law school environment as perceived by students should be positively linked to student engagement in educationally beneficial activities such as serious conversations with different ones in different racial and ethnic groups in terms of their personal values, political opinions, and religious beliefs.

First of all, with the concept of the rule of law, the realization of a truly functioning democracy with all its institutions and rules is possible with good lawyers. To be a good lawyer, judge and administrator, it is absolutely necessary to know and understand the law as well as to be a competent lawyer. A good lawyer should have a notion of law and formation. These two concepts are complementary.

In order to have a high-level notion of law and the formation, a person ought to receive a good education, have information at the highest level, put what they know into practice in the light of universal principles and rules of law, benefit from scientific opinion, follow the Supreme Court judgements, examine, review and assess the European Rights Convention and the European Court of Human Rights decisions, keep reading for self-improvement, produce something new in the field of law, if necessary. Individuals with these characteristics would be a good lawyer. For these reasons, the missions and visions of the schools of laws are very important to determine the target, and the Law students should be developed in accordance with the mission, vision and core values of the Schools of Law.

\section{REFERENCES}

[1] Gayechuway, J., (2008). Democracy: A Fleeting Elusion or a Possible Reality for Liberia? The Perspective. Atlanta, Georgia May 23, 2008.http://www.liberiaitech.com/thepersp ective/2008/0523200801.html

[2] Abington-Pitre, A.,(2015). Where did We Go Wrong? Eight Characteristics of a Multicultural Schools, p-101, Universal Journal of Educational Research 3(2): 99-103, 2015

[3] Burak, B., (2012). Turkey Today: A "Leviathan" or a "Law-seeker"? E-International Relations, April 252012. http://www.e-ir.info/2012/04/25/turkey-today-a-leviathan-or -a-law-seeker/

[4] Polese, A., (2010). The formal and the informal: exploring 'Ukrainian' Education in Ukraine, scenes from Odessa, Comparative Education, ps: 46-54-58, 15 Feb 2010, Roudledge.

[5] Janmaat, J.G. (2000). Nation Building in Post-Soviet Ukraine. Educational Policy and the Response of the Russian Speaking Population. Utrecht, Amsterdam: Royal Dutch Geographical Society

[6] Charles R. W. \& Trevor L. B. (1998) The consolidation of democracy in Ukraine, Democratization, 5:1, 116-137, DOI: $10.1080 / 13510349808403550$
[7] Boyko N., Herron E. S. \& Sverdan R., (2014) Administration and management of Ukraine's 2014 presidential election: a systematic and spatial analysis, Eurasian Geography and Economics, 55:3, 286-306, DOI: 10.1080/15387216.2014.98 6494

[8] Medvedev, O. (2007) The language balance of Ukraine. Modernity Issue 9, 68.

[9] Tereshchenko A. (2010) Ukrainian Youth and Civic Engagement: Unconventional Participation in Local Spaces, Journal of Youth Studies, 13:5, 597-613, DOI:10.1080/13676261.2010.487518

[10] Frye, T. (2015). What Do Voters in Ukraine Want?: A Survey Experiment on Candidate Ethnicity, Language, and Policy Orientation, Problems of Post-Communism, 62:5, 247-257, DOI: $10.1080 / 10758216.2015 .1026200$

[11] O'Sullivan, J. McNamara, J. (2015). Creating a global law graduate: The need, benefits and practical approaches to internationalize the curriculum, Journal of Learning Design, Special Issue: Legal Education, 2015 Vol. 8 No. 2, 53-65

[12] Katchanovski, I. (2012). Democracy and Political Values in Ukraine, 17th Annual World Convention of the Association for the Study of Nationalities at Columbia University, New York, NY, April 19-21, 2012

[13] Çermik, H., (2013). Öğretmen Adaylarının Demokratik Değerleri ve $\mathrm{Bu}$ Değerlerin Bazı Değișkenler Açısından İncelenmesi, NWSA-Education Sciences, 1C0586, 8, (2), 261-274

[14] Ferguson, A. (2015). Creating Practice Ready, Well and Professional Law Graduates, Journal of Learning Design, Special Issue: Legal Education, 2015 Vol. 8 No. 2, 22-37

[15] Gentile, M. (2010). Giving Voice to Values: How to Speak Your Mind When You Know What's Right. London: Yale University Press

[16] Erden, M. ve Akman, Y. (1996). Eğitim Psikolojisi - 3, p76. Arkadaş Yayınları, Ankara.

[17] Ersanl1, K., et al. (2005). Gelişim ve Öğrenme. (Editor: K. Ersanlı ve E. Uzman). P-195, Lisans Yayınc1lı, İstanbul.

[18] Selçuk, Z., (1996). Eğitim Psikolojisi. p 50, Pegem Yayınevi, Ankara

[19] Güzel, A., (1990). “Ailede Cocuk Eğitimi”, I. Aile Şurası Bildirileri, p-397 (17-20 Aralık 1990), Aile Araştırma Kurumu Başkanlığı Yayınları, Ankara

[20] Yeşil, R. and Aydın, D, (2009). Demokratik Değerlerin Eğitiminde Yöntem ve Zamanlama, p-79, TSA / Y11: 11, S: 2, Ağustos 2007

[21] Banks, J. A. (1993). Multicultural education: Historical development, dimensions, and practice, p-37. Review of Research in Education, 19, 3-49.

[22] Christie, C. A. L., (2009). Law School: A Multicultural Curriculum Design for Living in the 21st Century, Fall 2009.

[23] Anderson A. G. et al. (2008) Law School Survey of Student Engagement | 2008 A Annual Survey Results

[24] Anderson, A. G. Et al. (2005). The Law School Years: Probing Questions, Actionable Data, Law School Survey of Student Engagement, 2005 Annual Survey Results 